\title{
Replacement Time of Custom Ocular Prosthesis in Children: A Review Article
}

\author{
Saurabh Jain ${ }^{1}$, Khalil Ibrahim A Idris², Neda Essa M Al Omar ${ }^{3}$, Aeshah YM Atiah ${ }^{4}$, Afnan YM Atiah ${ }^{5}$, Aparna Aggarwal ${ }^{6}$
}

\begin{abstract}
The aim and objective of this article is to analyze the published literature on the replacement time of ocular prostheses in children. A systematic search of Indexed English literature up to November 31, 2020, was conducted. Data from PubMed, Scopus, and Cochrane library were searched for relevant manuscripts. Predefined inclusion and exclusion criteria were used by assessors, who inspected 910 manuscripts and selected 7 manuscripts, after analyzing their full texts. Because of the constant growth of the orbital socket in children, the ocular prosthesis has to be replaced till the growth of the orbit is complete. Custom ocular prosthesis requires recurrent relining or replacement, in growing children. The rate of relining or replacement of the prosthesis varies according to the growth of the orbit. Children with ocular prostheses should be appointed biannually or quarterly for routine examination. Yearly replacement or relining of the prosthesis should be conducted. Various factors, like patient comfort, age, signs, and clinical assessment, should be evaluated before relining or replacing the old prosthesis.
\end{abstract}

Keywords: Custom ocular prosthesis, Eye prosthesis for children, Maxillofacial prosthodontics, Ocular prosthesis, Stock ocular prosthesis. International Journal of Clinical Pediatric Dentistry (2021): 10.5005/jp-journals-10005-1978

\section{INTRODUCTION}

Loss of any vital organ of the body is a traumatic experience. In pediatric patients, loss of an eye is very common. Some of the most common reasons for the loss of an eye in pediatric patients are malignancy, trauma, congenital disorders, and infections. ${ }^{1}$

This loss of an eye, not only makes a child physically handicap but also has an everlasting psychological effect on him. Because of the constant growth of orbital sockets in a pediatric patient, it is necessary to replace this missing eye with an artificial prosthetic eye at an early stage. The shape and volume of the enucleated orbital socket should be preserved as any delay in the replacement prosthesis can cause asymmetrical growth of the enucleated side. This can cause major esthetic problems in the adult stage of life.

Various articles relate the growth of the orbital socket with the age. Literature available also suggests that as the child grows, the ocular prosthesis has to be replaced regularly with a new larger ocular prosthesis, till the growth is complete. This is necessary to prevent shrinkage of orbit and for adequate development of soft tissue and eyelids. ${ }^{2}$ There are no clear criteria that can guide the maxillofacial prosthodontist, regarding when and how frequently this prosthesis should be replaced in growing pediatric patients. This manuscript presents an overview of literature related to the growth of orbital bone and the need for replacing ocular prostheses in pediatric patients.

\section{Materials and Methods}

A systematic search of Indexed English literature up to November 30, 2020, was conducted. Data from PubMed, Scopus, and Cochrane library were searched for studies on replacement time of ocular prosthesis in children. Various word combinations like custom ocular prosthesis, ocular prosthesis, eye prosthesis for children, and stock ocular prosthesis were searched. Predefined inclusion and exclusion criteria were used by assessors, who inspected 910 manuscripts (Table 1). Duplicate articles were removed. Titles and abstracts were screened and full-text articles of shortlisted articles

\footnotetext{
${ }^{1}$ Department of Prosthetic Dental Sciences, College of Dentistry, Jazan University, Jazan, Kingdom of Saudi Arabia

${ }^{2-5}$ Private Practice, Jazan, Kingdom of Saudi Arabia

${ }^{6}$ Vitaldent Dental Clinic, Faridabad, Haryana, India
}

Corresponding Author: Saurabh Jain, Department of Prosthetic Dental Sciences, College of Dentistry, Jazan University, Jazan, Kingdom of Saudi Arabia, Phone: +966-550049588, e-mail: drsaurabhjain79@ gmail.com

How to cite this article: Jain S, Idris KIA, Al Omar NEM, et al. Replacement Time of Custom Ocular Prosthesis in Children: A Review Article. Int J Clin Pediatr Dent 2021;14(4):558-561.

Source of support: Nil

Conflict of interest: None

were thoroughly read. In the end, seven manuscripts were selected for this study.

\section{Orbital Growth Related to Age}

Table 2 shows the studies based on orbital growth relate to age. $\mathrm{Scott}^{3}$ did a study on the growth of the human face and concluded that there is a rapid increase in orbital volume until 3 years of age. By the age of 12 years, near-adult volume is achieved. Results of

Table 1: Inclusion and exclusion criteria

\begin{tabular}{|c|c|}
\hline Inclusion criteria & Exclusion criteria \\
\hline English language literature & Literature in a language other \\
\hline Human clinical studies & than English \\
\hline In vitro studies & Animal studies \\
\hline Studies on pediatric patients & Studies describing only \\
\hline \multirow{2}{*}{$\begin{array}{l}\text { Studies highlighting need to } \\
\text { replace the ocular prosthesis in } \\
\text { pediatric patients }\end{array}$} & ocular prosthesis \\
\hline & $\begin{array}{l}\text { Letters to editors and unpub- } \\
\text { lished abstracts and reports }\end{array}$ \\
\hline
\end{tabular}

OTheAuthor(s). 2021 Open Access This article is distributed under the terms of the Creative Commons Attribution 4.0 International License (https://creativecommons. org/licenses/by-nc/4.0/), which permits unrestricted use, distribution, and non-commercial reproduction in any medium, provided you give appropriate credit to the original author(s) and the source, provide a link to the Creative Commons license, and indicate if changes were made. The Creative Commons Public Domain Dedication waiver (http://creativecommons.org/publicdomain/zero/1.0/) applies to the data made available in this article, unless otherwise stated. 
Replacement Time of Ocular Prosthesis in Children

Table 2: Studies relating orbital growth to age

\begin{tabular}{|c|c|c|c|c|}
\hline Author & Study objective & Analysis method & Sample size & Outcome(s) \\
\hline $\operatorname{Scott}^{3}(1953)$ & $\begin{array}{l}\text { To study the growth of the } \\
\text { human face }\end{array}$ & X-rays & - & $\begin{array}{l}\text { Rapid increase in orbital volume till } 3 \text { years of age. } \\
\text { Near adult, orbital volume achieved till } 12 \text { years of } \\
\text { age. }\end{array}$ \\
\hline $\begin{array}{l}\text { Bartlett and } \\
\text { Moore }^{4}(1973)\end{array}$ & Studied orbital growth & $\begin{array}{l}\text { Opinions and asser- } \\
\text { tions }\end{array}$ & - & $\begin{array}{l}\text { - Orbital socket development completes at } 12 \text { years } \\
\text { of age. }\end{array}$ \\
\hline Furuta $^{5}(2001)$ & Measured orbital volume & $\begin{array}{l}\text { Reconstructed X-ray } \\
\text { computed tomogra- } \\
\text { phy }(\mathrm{CT}) \text { images }\end{array}$ & 109 & $\begin{array}{l}\text { - The rapid growth of the orbit comes to an end by } \\
15 \text { years of age in boys and by } 11 \text { years in girls. } \\
\text { - Greater than } 95 \% \text { of the growth of the adult orbit } \\
\text { has already been completed by the first half of the } \\
\text { teens. }\end{array}$ \\
\hline $\begin{array}{l}\text { Yago and } \\
\text { Furuta }^{6}(2001)\end{array}$ & $\begin{array}{l}\text { To study orbital growth af- } \\
\text { ter unilateral enucleation }\end{array}$ & $\begin{array}{l}\text { X-ray computed to- } \\
\text { mography images. }\end{array}$ & 5 & $\begin{array}{l}\text { - Orbital heights attained at age of } 3,7 \text {, and } 10 \text { years } \\
\text { were } 79,94 \text {, and } 97 \% \text { of adult size, respectively }\end{array}$ \\
\hline $\begin{array}{l}\text { Bentley et al. } \\
(2002)\end{array}$ & $\begin{array}{l}\text { To study normal changes } \\
\text { in orbital volume during } \\
\text { childhood }\end{array}$ & $\begin{array}{l}\text { Magnetic resonance } \\
\text { images }\end{array}$ & 67 & $\begin{array}{l}\text { Orbital volume increases till } 15 \text { years of age in both } \\
\text { males and females. } \\
\text { - } 77 \% \text { of the total orbital volume is achieved by age } \\
\text { of } 5 \text { years. } \\
\text { - Orbital volume is more in males as compared to } \\
\text { females. }\end{array}$ \\
\hline $\begin{array}{l}\text { Chau et al. } \\
\text { (2004) }\end{array}$ & $\begin{array}{l}\text { To study orbital develop- } \\
\text { ment by measuring orbital } \\
\text { volume }\end{array}$ & $\begin{array}{l}\text { Magnetic resonance } \\
\text { images }\end{array}$ & 81 & $\begin{array}{l}\text { - Orbit grows till about } 16 \text { years of age. } \\
\text { - } 75 \% \text { growth in an orbit seen from } 1 \text { to } 3 \text { years of } \\
\text { age. } \\
\text { - } 25 \% \text { growth seen from } 4 \text { to } 16 \text { years of age. }\end{array}$ \\
\hline Ji et al. ${ }^{9}(2015)$ & $\begin{array}{l}\text { Analyze bony orbital } \\
\text { maldevelopment after } \\
\text { enucleation }\end{array}$ & $\begin{array}{l}\text { Computer tomogra- } \\
\text { phy scans }\end{array}$ & 87 & $\begin{array}{l}\text { - Orbital growth takes till } 18 \text { years of age. } \\
\text { Enucleating the orbit during the growth phase } \\
\text { reduces the growth rate of that side, but does not } \\
\text { stop the growth completely. }\end{array}$ \\
\hline
\end{tabular}

the study done by Bartlett and Moore ${ }^{4}$ were also in agreement with those of Scott that the orbital socket development completes at 12 years of age. Furuta ${ }^{5}$ used reconstructed X-ray computed tomography (CT) images to measure orbital volume in 109 subjects and studied its changes with age. He concluded that rapid growth of the orbit comes to an end by 15 years of age in boys and by 11 years in girls. He also reported that $>95 \%$ of the growth of the adult orbit is completed by the first half of the teenage.

Yago and Furuta ${ }^{6}$ did a clinical study on orbital growth after unilateral enucleation in five patients using X-ray computed tomographic images and concluded that orbital heights attained at age of 3, 7, and 10 years were 79,94 , and $97 \%$ of adult size, respectively. Bentley et al. ${ }^{7}$ studied normal changes in orbital volume during childhood in 67 patients using magnetic resonance images and found that orbital volume increases till 15 years of age in both males and females. He also concluded that $77 \%$ of the total orbital volume is achieved by age of 5 years and the orbital volume is more in males as compared to females.

Chau et al. ${ }^{8}$ did a clinical study on orbital development by measuring orbital volume in 81 patients using magnetic resonance images and concluded that orbit grows till about 16 years of age. Seventy-five percent growth in orbit is seen from 1 to 3 years of age and the remaining $25 \%$ growth is seen from 4 to 16 years of age. Ji et al. ${ }^{9}$ used a computer tomography scan to analyze bony orbital maldevelopment after enucleation in 87 patients. They concluded that orbital growth takes till 18 years of age. Enucleating the orbit during the growth phase reduces the growth rate of that side, but does not stop the growth completely.

\section{Replacement Time of Ocular Prosthesis in Children}

Table 3 shows the studies based on replacement time of ocular prosthesis in children. All the studies stressed the fact that in growing children, the ocular prosthesis should be changed periodically over the growth years.

Zekman et al. ${ }^{10}$ stated that periodic enlargement of a custom ocular prosthesis is required in a growing child. A gradual increase in the size of the prosthesis is required over the period of time to assist in the normal development of eyelids and soft tissues lining the orbital bone margins. They also stated that the presence of a prosthesis is not necessary for normal bone growth. Bartlett and Moore ${ }^{4}$ also stressed that to keep pace with the child's growth, the ocular prosthesis should be refabricated at regular intervals.

Lorenzana et al. ${ }^{11}$ gave a guideline for refitting the ocular prosthesis in pediatric patients. They stated that, for pediatric patients, the ocular prosthesis should be refitted every year, and recall appointments should be scheduled every three months. Mattos et al. ${ }^{12}$ surveyed 124 child patients who need ocular prosthesis and stated that periodic change by increasing the size of ocular prosthesis is required to cope up with the expansion of the anophthalmic cavity.

Raizada et al. ${ }^{13}$ did a retrospective review evaluating the replacement schedule of the custom ocular prosthesis in children. They concluded that ocular prosthesis in $41 \%$ of the children requires a change between 18 months and 26 months after placement. They also found that replacement needs and schedule varies with age with $47 \%$ of children with $\leq 3$ years of age required change in the ocular prosthesis in a mean duration of 18 months. Forty-three 
Table 3: Studies on replacement time of ocular prosthesis in a child patient

\begin{tabular}{|c|c|c|c|c|}
\hline Author & Study objective & Analysis method & Sample size & Outcome(s) \\
\hline $\begin{array}{l}\text { Zekman et } \\
\text { al. }^{10}(1955)\end{array}$ & $\begin{array}{l}\text { Fabrication of the } \\
\text { ocular prosthesis }\end{array}$ & - & - & $\begin{array}{l}\text { Periodic enlargement of the custom ocular prosthesis } \\
\text { is required in a growing child. To assist in the normal } \\
\text { development of eyelids and soft tissues lining the orbital bone } \\
\text { margins, a gradual increase in the size of the prosthesis over a } \\
\text { period of years is done. He also stated that the presence of a } \\
\text { prosthesis is not necessary for normal bone growth. }\end{array}$ \\
\hline $\begin{array}{l}\text { Bartlett and } \\
\text { Moore }^{4}(1973)\end{array}$ & $\begin{array}{l}\text { Steps for ocu- } \\
\text { lar prosthesis } \\
\text { fabrication }\end{array}$ & $\begin{array}{l}\text { Opinions and asser- } \\
\text { tions }\end{array}$ & - & $\begin{array}{l}\text { - To keep pace with the child's growth, the ocular prosthesis } \\
\text { should be remade at regular intervals. }\end{array}$ \\
\hline $\begin{array}{l}\text { Lorenzana } \\
\text { et al. }{ }^{11}(2000)\end{array}$ & $\begin{array}{l}\text { Ocular prosthesis } \\
\text { management in a } \\
\text { pediatric patient }\end{array}$ & Case report & 1 & $\begin{array}{l}\text { For pediatric patients, the ocular prosthesis should be refitted } \\
\text { every year, and a recall appointment should be scheduled } \\
\text { every } 3 \text { months. }\end{array}$ \\
\hline $\begin{array}{l}\text { Mattos et al. }{ }^{12} \\
(2006)\end{array}$ & $\begin{array}{l}\text { To characterize } \\
\text { a profile of the } \\
\text { child patients who } \\
\text { need an ocular } \\
\text { prosthesis }\end{array}$ & Survey & 124 & $\begin{array}{l}\text { Periodic change by increasing the size of the ocular prosthesis } \\
\text { is required to cope up with the expansion of the anophthalmic } \\
\text { cavity. }\end{array}$ \\
\hline $\begin{array}{l}\text { Raizada } \\
\text { et al. }{ }^{13}(2011)\end{array}$ & $\begin{array}{l}\text { To know the } \\
\text { replacement } \\
\text { schedule of } \\
\text { custom ocular } \\
\text { prosthesis }\end{array}$ & $\begin{array}{l}\text { A retrospective } \\
\text { review evaluating the } \\
\text { replacement schedule } \\
\text { of custom ocular pros- } \\
\text { thesis in children }\end{array}$ & 330 & $\begin{array}{l}\text { - Ocular prosthesis in } 41 \% \text { of the children requires a change } \\
\text { between } 18 \text { months and } 26 \text { months after placement. } \\
\text { - } \text { Replacement needs and schedule varies with age } \\
\text { - } 47 \% \text { in children } \leq 3 \text { years (mean duration } 18 \text { months) } \\
\text { - } 43 \% \text { in } 3-12 \text {-year age group (mean duration } 21 \text { months) } \\
\text { - } 29 \% \text { in } 12-16 \text {-year age group (mean duration } 26 \text { months) }\end{array}$ \\
\hline $\begin{array}{l}\text { Shaikh et al. }{ }^{14} \\
(2014)\end{array}$ & $\begin{array}{l}\text { Management of } \\
\text { ocular prosthesis } \\
\text { in growing patient }\end{array}$ & Case report & 1 & $\begin{array}{l}\text { Custom ocular prosthesis needs to be changed till the age } \\
\text { of } 12 \text { years based on the clinical evaluation and presence of } \\
\text { symptoms in coordination with the facial growth. }\end{array}$ \\
\hline $\begin{array}{l}\text { Pascale }^{15} \\
(2016)\end{array}$ & $\begin{array}{l}\text { Tips for fitting eye } \\
\text { prostheses for the } \\
\text { pediatric patient } \\
\text { after enucleation }\end{array}$ & Clinical tips & - & $\begin{array}{l}\text { The ocular prosthesis should be checked every } 6 \text { months for } \\
\text { fit, size, and comfort till the child grows and up until the age } \\
\text { of } 8 \text {. }\end{array}$ \\
\hline
\end{tabular}

percent of children in the 3 to 12-year age group required change in the ocular prosthesis in a mean duration of 21 months. While only $29 \%$ of children in the 12 to 16 -year age group required change in the ocular prosthesis in a mean duration of 26 months.

Shaikh et al. ${ }^{14}$ stated that custom ocular prosthesis needs to be changed till the age of 12 years based on the clinical evaluation and presence of symptoms in coordination with the facial growth. Pascale ${ }^{15}$ stated that ocular prosthesis should be checked every 6 months for fit, size, and comfort till the child is 8 years old.

Based on the review of the literature, we can state that these patients should be recalled regularly and clinical evaluation should be related to the presence of symptoms in coordination with the facial growth. Some of the common indications for change in the ocular prosthesis in pediatric patients are loose fit, prosthesis rotation within the socket, decentration of the cornea, enophthalmic prosthesis, cosmetically significant Ptosis, discoloration of the prosthesis. ${ }^{13}$

All the studies stressed the fact that in growing children, the ocular prosthesis should be changed periodically over the period of years. But there are very few studies that can guide the formulation of protocols and plans for changing ocular prosthesis, relating to growth. This change in the prosthesis is necessary for congruent facial development and to reduce growth discrepancy in enucleated orbit.

\section{CONCLUSION}

Because of the constant growth of the orbital socket in children, the ocular prosthesis has to be replaced till the growth of the orbit is complete. Custom ocular prosthesis requires recurrent relining or replacement, in growing children. The rate of relining or replacement of the prosthesis varies according to the growth of the orbit. Children with ocular prostheses should be appointed biannually or quarterly for routine examination. Yearly replacement or relining of the prosthesis should be conducted. Various factors, like patient comfort, age, signs, symptoms, and clinical assessment, should be evaluated before relining or replacing the old ocular prosthesis.

\section{References}

1. Raflo GT. Enucleation and evisceration. In: Tasmun W, Jaeger E, ed. Duane's clinical ophthalmology. Revised ed., vol. 5, Philadelphia: Lippincott-Raven; 1995. p. 1-25.

2. Cain JR. Custom ocular prosthetics. J Prosthet Dent 1982;48(6):690694. DOI: 10.1016/s0022-3913(82)80030-9.

3. Scott JH. Growth of the human face. Proc R Soc Med 1953;47:91-100.

4. Bartlett SO, Moore DJ. Ocular prosthesis: a physiologic system. J Prosthet Dent 1973;29(4):450-459. DOI: 10.1016/s0022-3913(73) 80024-1. 
5. Furuta M. Measurement of orbital volume by computed tomography: especially on the growth of the orbit. Jpn J Ophthalmol 2001;45(6):600-606. DOI: 10.1016/s0021-5155(01)00419-1.

6. Yago K, Furuta M. Orbital growth after unilateral enucleation in infancy without an orbital implant. Jpn J Ophthalmol 2001;45(6):648652. DOI: 10.1016/s0021-5155(01)00427-0.

7. Bentley RP, Sgouros S, Natarajan K, et al. Normal changes in orbital volume during childhood. J Neurosurg 2002;96(4):742-746. DOI: 10.3171/jns.2002.96.4.0742.

8. Chau A, Fung K, Yip L, et al. Orbital development in Hong Kong Chinese subjects. Ophthalmic Physiol Opt 2004;24(5):436-439. DOl: 10.1111/j.1475-1313.2004.00217.x.

9. Ji $\mathrm{Y}, \mathrm{Ye} \mathrm{F}$, Zhou $\mathrm{H}$, et al. Bony orbital maldevelopment after enucleation. J Anat 2015;227(5):647-653. DOI: 10.1111/joa.12372.

10. Zekman TN, Ladenheim J, Scott RB. Ocular prosthetics. AMA Arch Ophthalmol 1955;54(5):733-743. DOI: 10.1001/archo pht.1955.00930020739017.
11. Lorenzana IJ, Strako D, Adkins. PG, Ocular prosthesis managmenet in a pediatric patient Ingryd Lorenzana, Abstract in clinical education and case Reports. Northern Hemisphere Sat Dec 9, 2000 Poster \# 121 (PO-142), Illinois College of Optometry, Chiacago. Presented at American Academy of Optometry.

12. Mattos BSC, Montagna MC, Fernandes CS, et al. The pediatric patient at a maxillofacial service - eye prosthesis. Braz Oral Res 2006;20(3):247-251. DOI: 10.1590/s1806-83242006000300012.

13. Raizada D, Raizada K, Naik M, et al. Custom ocular prosthesis in children: how often is a change required? Orbit 2011;30(5):208-213. DOI: 10.3109/01676830.2011.580035.

14. Shaikh SR, Gangurde AP, Shambharkar VI. Changing ocular prostheses in growing children: a 5-year follow-up clinical report J Prosthet Dent 2014;111(4):346-348. DOI: 10.1016/j.prosdent.2013. 09.021.

15. Pascale S. Tips for fitting eye prostheses for the pediatric patient after enucleation. US Ophthal Rev 2016;9(1):49-52. DOI: 10.17925/ USOR.2016.09.01.49. 